\title{
Design of equipment for sail cloth life cycle assessment ${ }^{\prime}$
}

\author{
Viviane Pestano, Alexandra Xerxenevsky, Luis Henrique Alves Cândido \\ Universidade Federal do Rio Grande do Sul \\ e-mails: vivianepestano@gmail.com; alexandra.jmx@gmail.com; candido@ufrgs.br
}

\begin{abstract}
This study aimed to develop equipment to sail cloth life cycle assessment. Analytical screenings of testing sample were carried out using FTIR (Fourier Transform InfraRed), SEM (Scanning electron microscope-desktop) and VIVID 9i (3d laser scanner). The comparison between virgin and discarded materials was used to validate the test results. A wind tunnel prototype was built to assess fabric stretch. The test results showed a difference in curvature between both materials. In addition to this analysis, the SEM images revealed that when the threads are stretched they tend to form a pocket, which may have a negative effect on sailing performance. However, discarded materials can be used on boats for nautical sports training or recreational activities. These results can be useful in the design of products for material life cycle assessment and their application in sailing and related fields.
\end{abstract}

Keywords: life cycle, boat sails, polyester, product design.

\section{Introduction}

Sports technology has been developing very rapidly mainly due to multi-sport competitions and design plays an important role both in improving and creating equipments. Athletes rely on technology and studies that involve bionics, mechanics, and materials to exceed their limits (SCHLEIFER, 2004).

The history of sports is as old as humankind and often involved the preparation and training for war or hunting, and men had to create new techniques and equipments. Currently, there are hundreds of modalities of world-renowned sports (DUARTE, 2003).

Apart from all these perspectives and analysis for the development of new sports products, design applied to sports faces a unique challenge: to determine the life cycle of materials used to manufacture equipment. It is of paramount importance to keep up with innovation in equipments and materials, combining it with reuse and proper disposal of their components (CÂNDIDO, 2008).

The choice of suitable material for sports equipments is essential for developing great athletes. The use of technological textiles can surely play a role in the enhancement of that equipment. Undoubtedly, a better understanding of the effects of aerodynamics on a specific textile material can improve personal sports gear such as clothing and shoes or any other project in sports design (CHOWDHURY, 2012).

\subsection{Sailboats}

There are several types of sailboats. However, for a brief understanding of the motion dynamics of these vessels, we will describe the most common boat design in use - monohull boat.

\footnotetext{
${ }^{1}$ Enhanced version of an article previously published in the proceedings of IDEMI 2015 (IV Conferência Internacional de Design, Engenharia e Gestão para a Inovação)
}

The monohull sailing boats are classified into two categories: ocean sailing boats (Figure 1), which can hold four to twelve crew members; and monotypes (Figure 2), smaller vessels that allow up to four crew members. These boats measure $2.5 \mathrm{~m}$ to $24 \mathrm{~m}$. These measurements are defined by LOA (length overall), which is the measurement from the leading edge of the bow to the end of the stern (ASSOCIAÇÃO..., 2011).

What propels the boat forward is the wind that presses directly into the sails to make them puff out. Figure 3 shows the diagram of a common sailboat and its main parts: the mast, a long upright pole that holds up the mainsail and the jib: The keel, a long, slim plank that juts out from the bottom of the hull, provides an underwater balancing force that keeps the boat from tipping over, and the ballast is lead.

Figure 4 shows the motion dynamics of this type of sailboat and the force exerted by the wind and by the keel in the water. In the force diagram (Figure 4), the sails interact with the wind coming from the left, pushing the boat to the right. The keel has two main functions: to keep the boat from being blown sideways in the wind (lateral resistance) and to hold the ballast. When a boat heels, or tips sideways in one direction when tacking, the ballast prevents it from going completely over (PALMER, 2005). The sideway force somehow makes the boat move forward as the force exerted by the water reacts to the lateral resistance of the wind (CAETANO, 2015).

Sailboat design configuration ensures that the center of mass for the sailboat will be somewhere in the keel. The buoyancy force acts through the geometric center of the sailboat. The separation between the buoyancy and the gravitational force vectors is what causes the counterbalancing torque. The air moving across the sails, 
like air moving across an airplane wing, is based on the same principle (Bernoulli's Principle) (Figure 5), which explains why sails are built with a similar format of airplane wings. The driving force created by the sail makes the sailboat move (PALMER, 2005). Sails on boats provide thrust in a horizontal direction derived from moving air, and wings

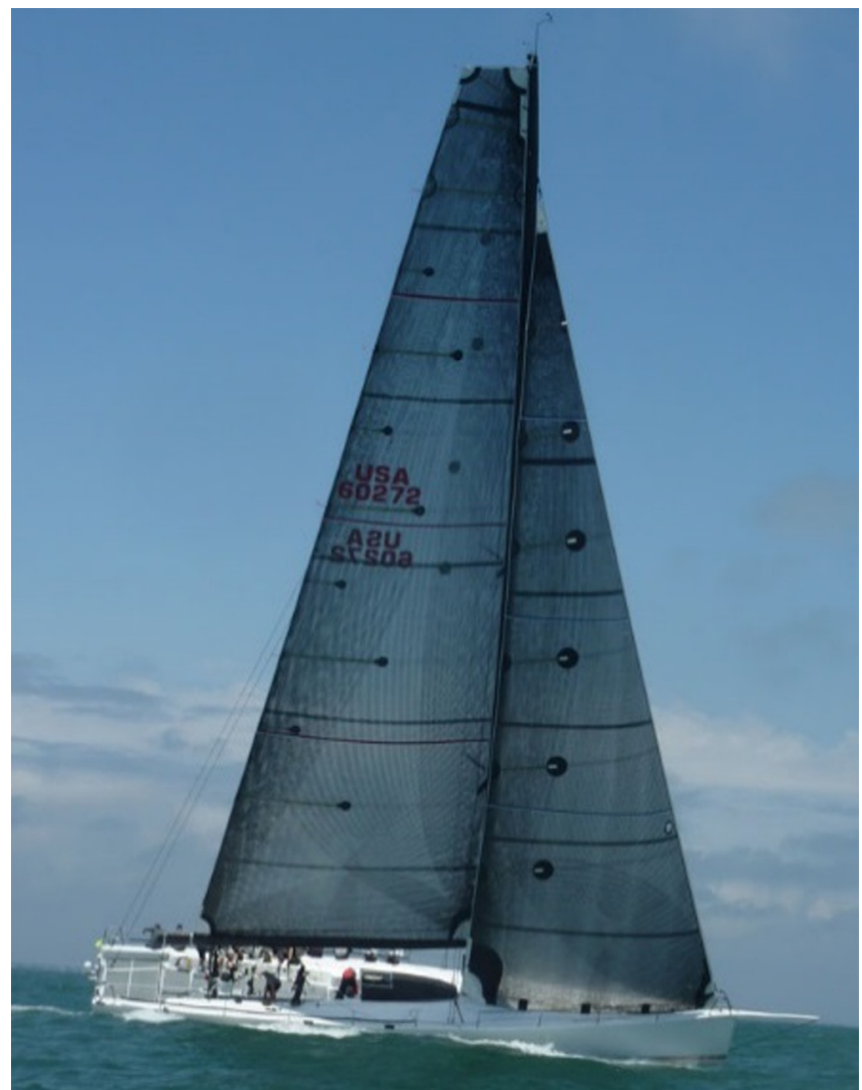

Figure 1. SOTO 40 ocean sailboat. Photo: Doylesails (2015).

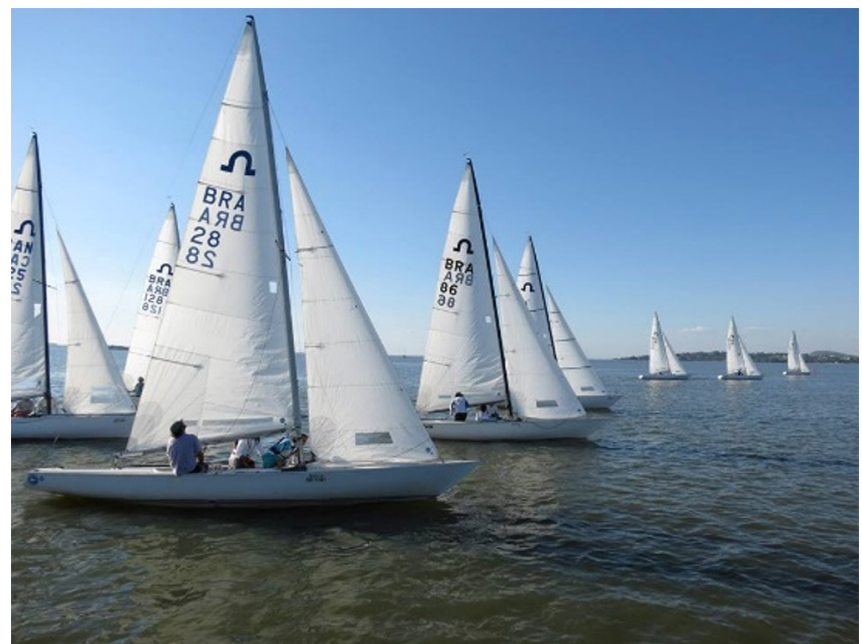

Figure 2. Monohull sailboat - Soling class racing sailboat. Photo: elaborated by the author-Clube Jangadeiros de Porto Alegre.

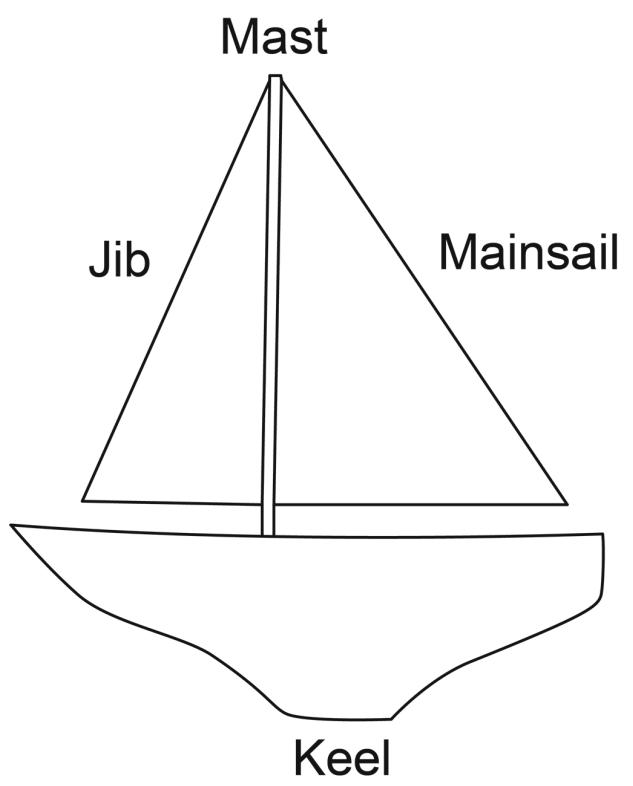

Figure 3. Diagram of a typical sailboat (PALMER, 2005).

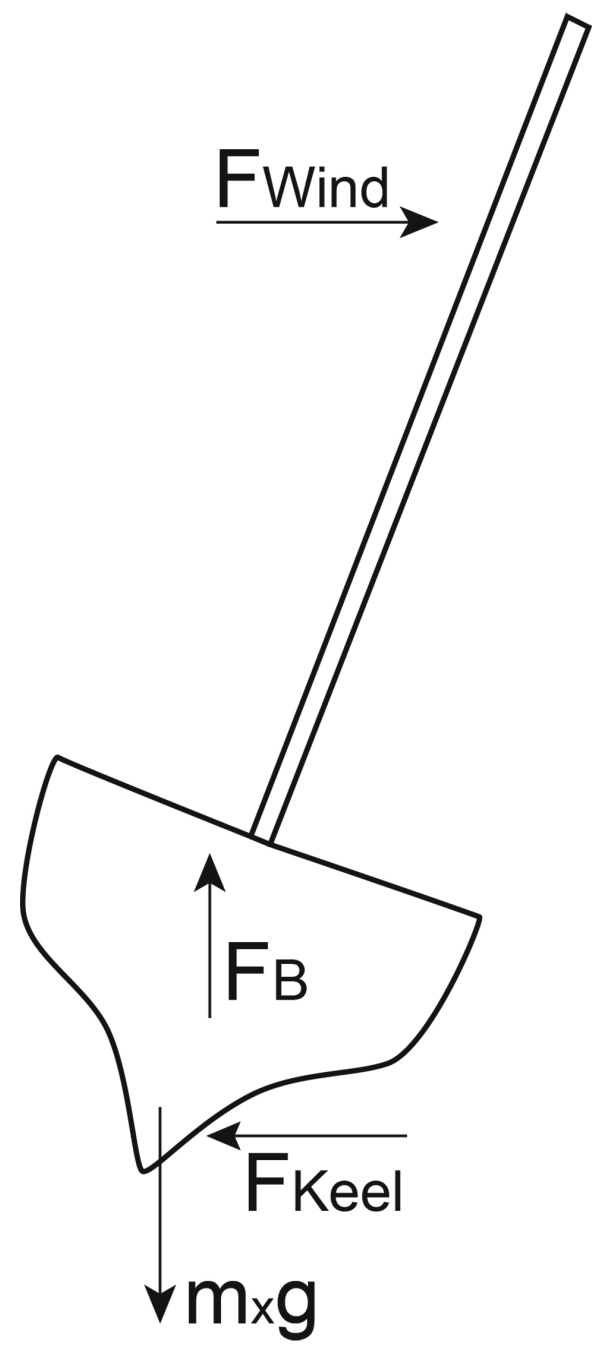

Figure 4. Diagram of the sailboat force dynamics (PALMER, 2005). 

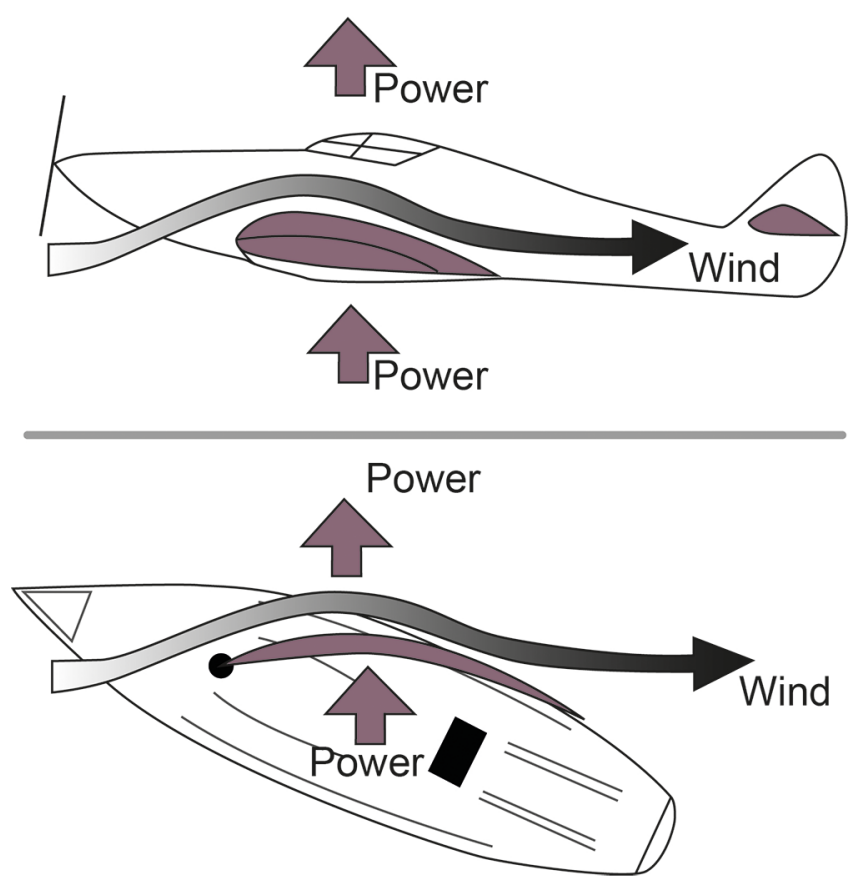

Figure 5. Schematic comparison between sails on boats and wings of aircraft (CAETANO, 2015).

on aircraft provide "lift" in a vertical direction to support a plane in the air (CAETANO, 2015).

\subsection{Evolution of sails}

The creation of a sail was important for maritime transport in the facilitation and development of trade in different parts of the world, initially to carry cargo and later to transport people. The initial solution for the sail format (square) was identical in the three seas: the Indian, the Pacific, and the Mediterranean. Square sails were attached to crossbars that ran across the width (beam) of the boat (Figure 6) and helped the sail to remain open. This type of sail had limited maneuverability and depended on the position of the mast and the direction of the wind. The boat could only sail windward. All of the forces were in the same direction. In any other wind direction, the boat needed to be pulled ashore or remained anchored waiting for winds (AZEVEDO, 2008).

Lateen sail, a triangular sail, was of decisive importance to medieval navigation (Figure 7). The ancient square sail permitted sailing only before the wind; the lanteen was the earliest fore-and-aft sail. Its free corner secured near the stern, was capable of taking the wind on either side. Both sails were used in the Portuguese caravels, and after these changes, were capable of long ocean crossings (AZEVEDO, 2008).

Historically, the most commonly used type of sailcloth was linen, which needed to be watered constantly to provide more wind pressure on the fabric to make the boat move on

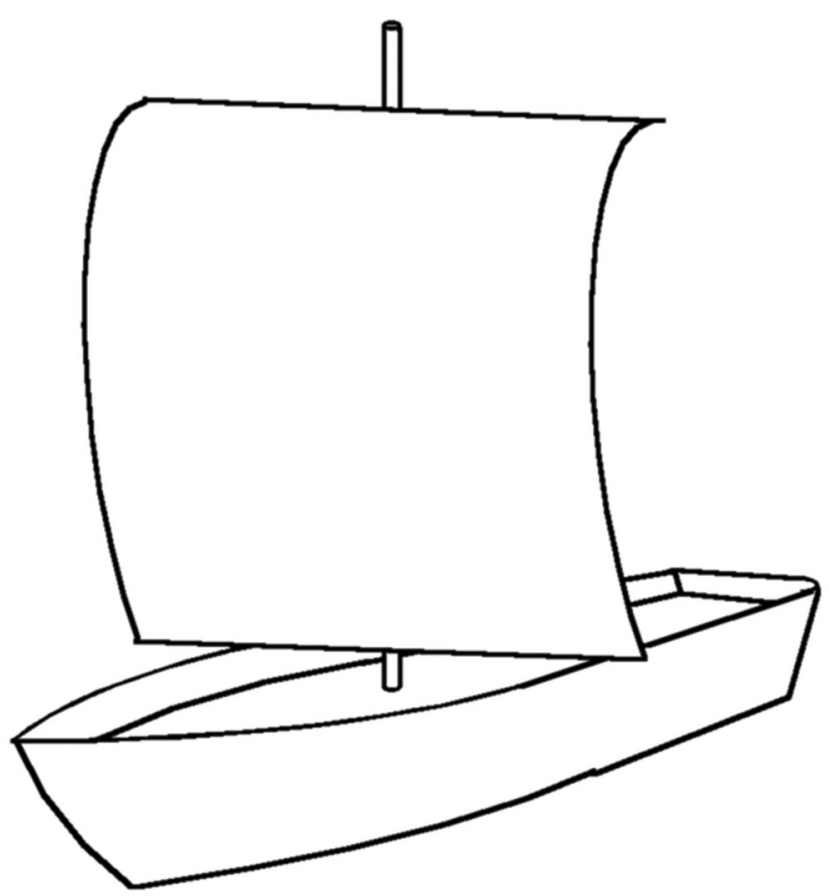

Figure 6. Diagram of a square sail (AZEVEDO, 2008).

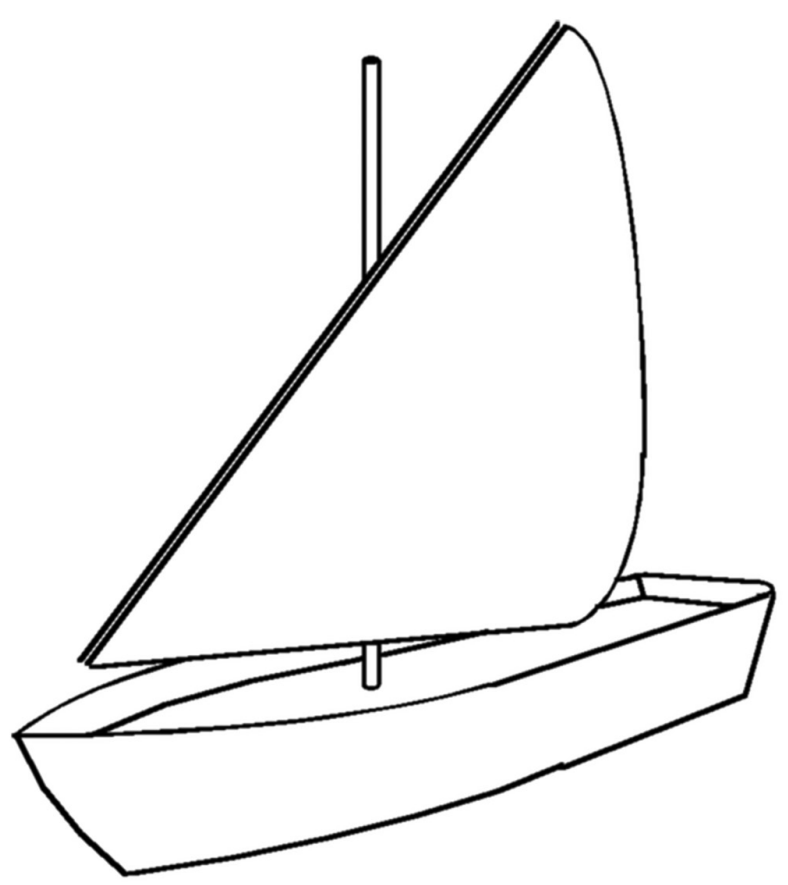

Figure 7. Diagram of lanteen sail (AZEVEDO, 2008).

its course to full strength. Today, the most frequently used types of woven sailcloth are fiber materials and flexible polymeric resins. These sail cloths provide impermeability, are more resistance to abrasion, protect the material from the degradation caused by the sun and moisture and are lightweight (MÉRIDA; FANGUEIRO, 2012). 


\subsection{Sail market}

The sail market is promising for the nautical sector. The strong interest and the business generated during boat shows reveal a prosperous future. According to Márcio Dottori, Technical Director of the Boat Show,

Brazil has about 700 thousand leisure boats - average of one boat for every 277 inhabitants. In France, it is one for every 63. In the United States, it is one for every 23. And in Sweden, the average is a boat for every 7 inhabitants. (BATISTA, 2012).

For Dottori, the number of vessels will double until 2020, and Brazil will have one boat for every 135 inhabitants (BATISTA, 2012). This data made us conclude that the life cycle of sail cloths should be investigated to find a solution for their disposal that would probably happen in the long term.

\subsection{Sail cloths}

The technological textile sector continues to grow and in the case of sail cloths is no different. Competition vessels require improvements and the industry responds with new techniques of lamination and various methods of building structures and load-path.

Information about sail cloths has been obtained from Challenge Sailcloth (2014), a global producer of the highest quality sail cloth, custom, marine and industrial fabrics. This company discloses research material, which include manufacturing techniques of canvas construction and advances. These technological developments introduced to vessel competitions cause a frequent replacement of sails and produces sail cloth leftovers, according to what was revealed in an interview with a representative of Olympic Sails (2014), a specialized company in the design of yacht sails. On average, sails used in high performance boats are replaced every 5 years at most to keep competitors among the fastest of this modality.

Due to this early replacement, we decided to perform tests to determine what has affected the sail's performance. To do so, disposed cloths and new patches of Dacron (the primary sail material for fore and aft sails) were collected. The specifications provided by the manufacturer indicate low stretch levels, which are produced with highly carved solid polyester yarns that are immersed in resin. Therefore, the main purpose of this study was to assess the composites, the weaves and durability of sail cloths and their possible reuse or recycling.

\section{Material and methods}

The materials used for the analysis were donated by a sail factory located in Porto Alegre, RS - Brazil. Considering that most of the sails were being produced with the use of Dracon fabrics, this material was defined as the Virgin material for testing.

Two different weights were used for the new fabrics: Dacron 1 - in sails for boats measuring 27-31', and Dacron 2 - in sails for boats measuring 42-48' (CHALLENGE SAILCLOTH, 2014). The disposed sails were provided by a sailing school (Porto Alegre/RS) and named Dacron 3. These sails were being used in a 2.4 MR Paralympics category measuring $7^{\prime}$. Three specimens were obtained from Dacron 3 (Figure 8), and were called Dacron $3_{\mathrm{T}}$ - a piece of cloth taken from the sail top; Dacron $3_{\mathrm{M}}$ - a piece taken from the center of the sail; and Dacron $3_{\mathrm{B}}$ - piece removed from the base of the sail, respectively. These three distinctive parts showed which area were more affected by the wind force i.e. the load path.

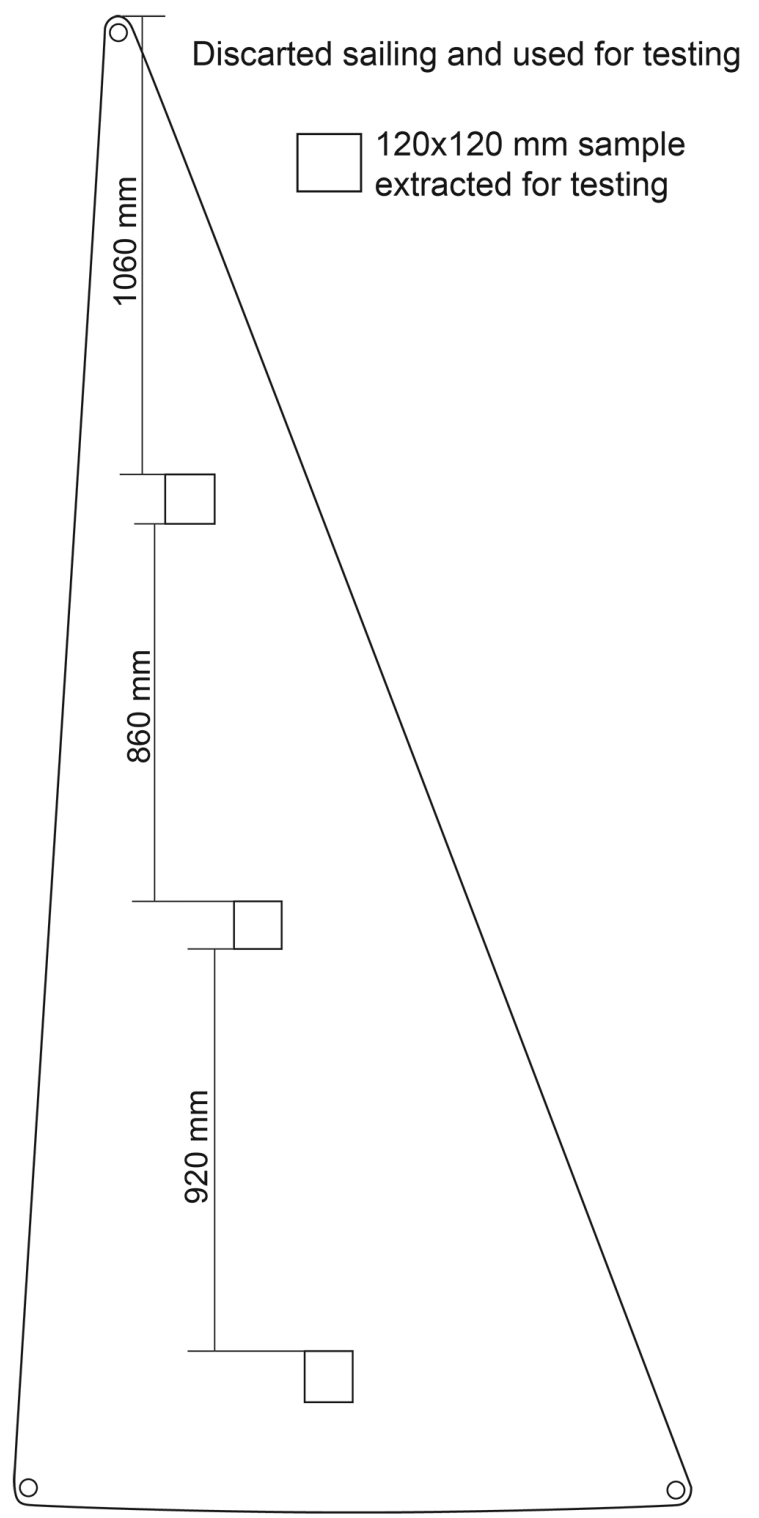

Figure 8. Design and analysis of the disposed sail sample. 


\subsection{FT-IR testing}

To perform the FT-IR testing, the three samples of Dacron (1, 2 and 3$)$ were fractionated into portions. The test was used to determine the type of polymer used in the weave. Figure 9 shows the results obtained from infrared spectroscopy.

The base result matched the FT-IR spectrometer database (BIO-RAD), whose information was given by the commercial name of virgin materials. Table 1 shows the first two brands that manufacture the product. Data regarding the type of virgin material was provided by the manufacturers. The comparison between the peak area measurements of the sample determined polyester (PES) as the virgin material of the three samples.

The results confirmed the information provided by the manufacturer. The characteristics of polyester reveal excellent resiliency, high abrasion and UV resistance, high flex strength. It is also thermoplastic and does not break down easily. This fiber retains its shape even when affected by moisture or dry weather. It presents good resistance to insect damage and mildew, to synthetic and natural chemicals and low absorption rate (KUASNE, 2008). All characteristics meet the needs for this type of product.

\subsection{Scanning electron microscope- desktop}

Different weaves can be observed in the virgin fabric (Dacron 1 and 2) due to the expected performance of the material and will be proportional to the size of the boat.

Figure 10 shows a sample of Dacron 1. Its weave is less tight, containing less polyester yarns per millimeter compared with Dacron 2 (Figure 11), where the weave is tighter with more polyester yarns per millimeter.

SEM images (Figures 12, 13 and 14) were obtained from 3 different parts of the Dacron fabric: $3_{\mathrm{B}} 3_{\mathrm{M}}$ and $3_{\mathrm{T}}$, respectively. The behavior of these three points was analyzed to determine the area with the highest stress suffered by the action of the wind.

The visual analysis of the differences between the three areas of the Dracon 3 was used to determine the fabric measurements. The mean values of the higher dimensions are shown in Table 2.

The analysis revealed that the fibers were spread apart and their weave were less tight in Dacron $3_{\mathrm{M}}$ specimen when the three parts were compared. In addition, the fibers of three samples were distorted, when compared with the virgin samples (Dacron 1 and 2).

\subsection{Design of a wind tunnel and 3D scanning}

For this test, a prototype was built to allow the insertion of controlled compressed air (Figure 15). Software was used to develop the wind tunnel.

Table 1. Commercial names of materials.

\begin{tabular}{|c|c|}
\hline Fabric & Commercial Name \\
\hline \multirow{2}{*}{ Dacron 1} & MELINEX 377/200 \\
& SCOTCH PAK N. 221 \\
\hline \multirow{2}{*}{ Dacron 2} & MELINEX 377/200 \\
& SCOTCH PAK N. 221 \\
\hline \multirow{2}{*}{ Dacron 3 } & MELINEX 377/200 \\
& SCOTCH PAK N. 221 \\
\hline
\end{tabular}

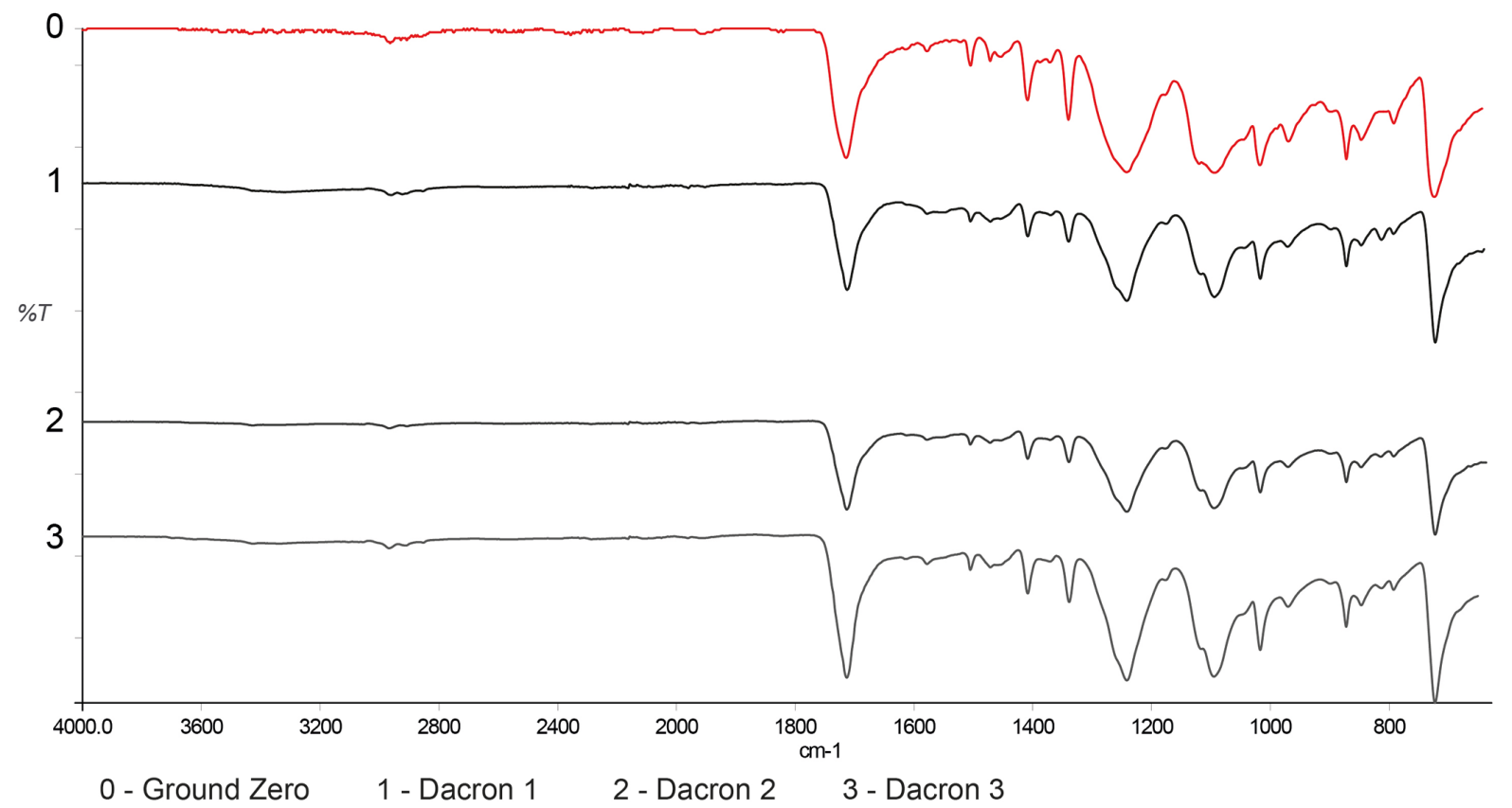

Figure 9. FT-IR graph results for Dacron (1,2, and 3) and the base result (0). 


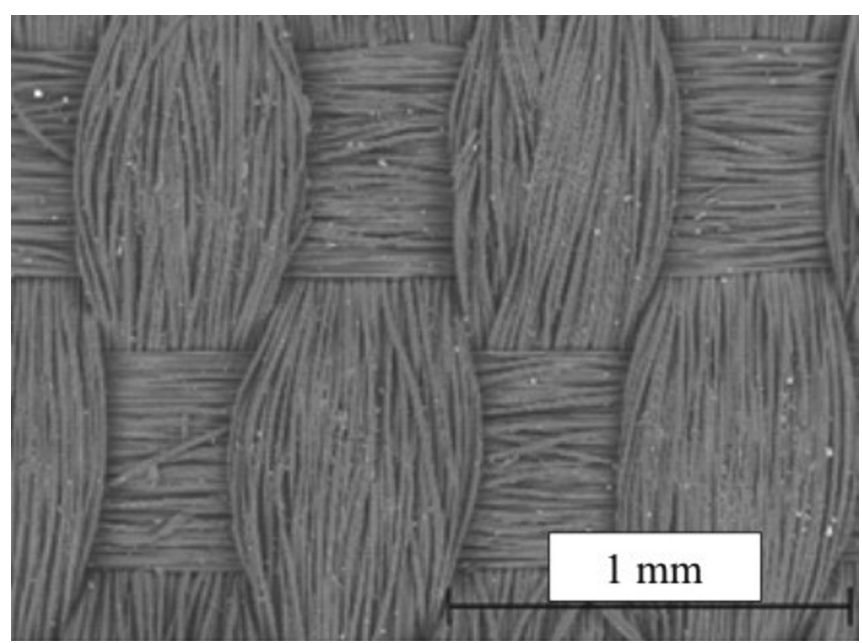

Figure 10. Weave in Dacron 1is less tight, containing less polyester yarns per millimeter. Amplified image $80 \times$.

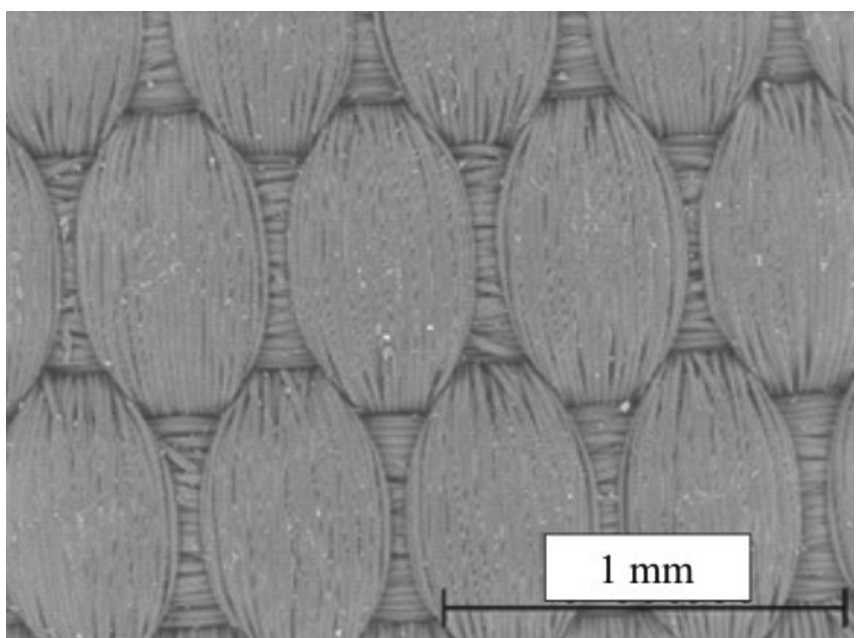

Figure 11. Weave in Dacron 2 is tighter with more polyester yarns per millimeter. Amplified image $80 \times$.

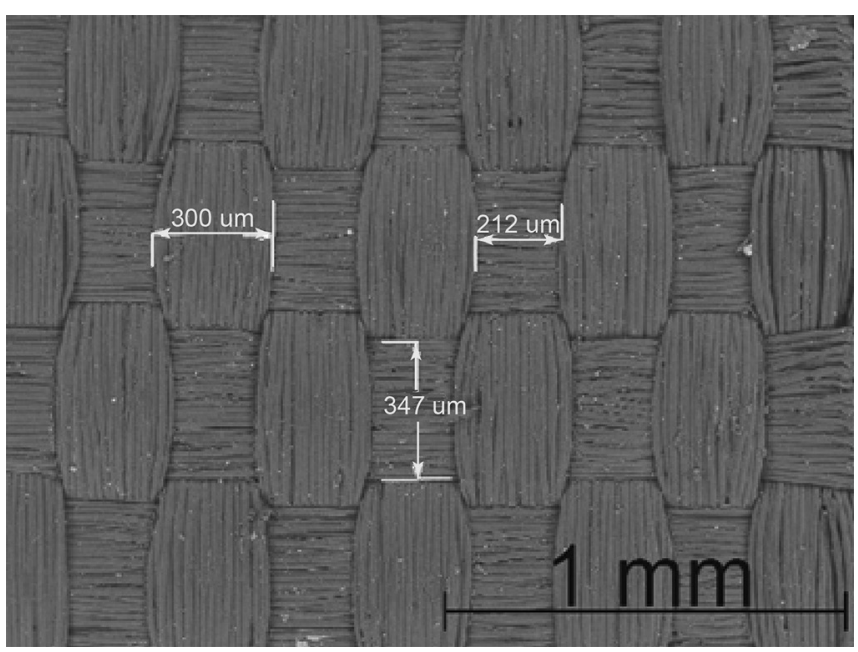

Figure 12. Dacron 3 . Amplified SEM image $80 \times$.

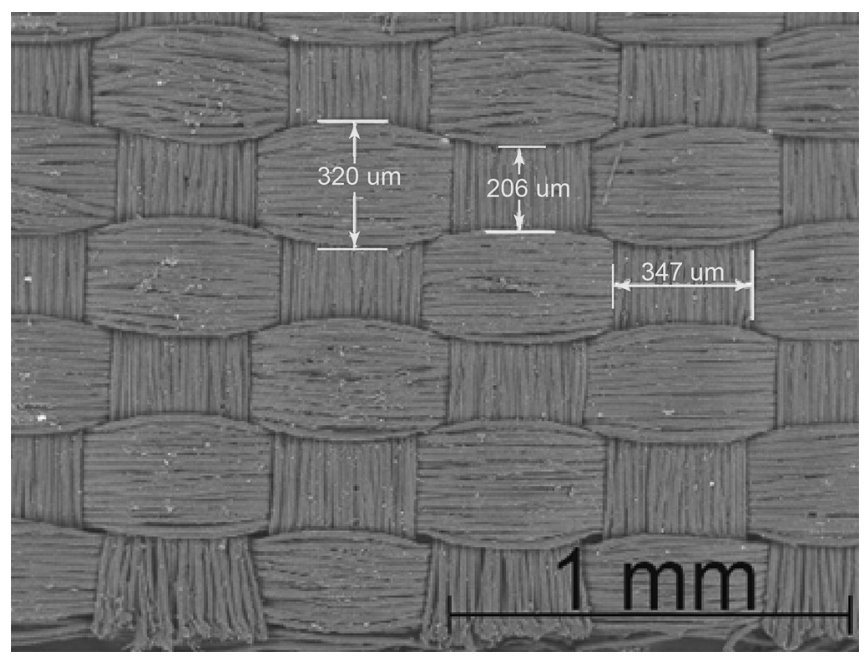

Figure 13. Dacron $3_{\mathrm{M}}$. Amplified SEM image $80 \times$.

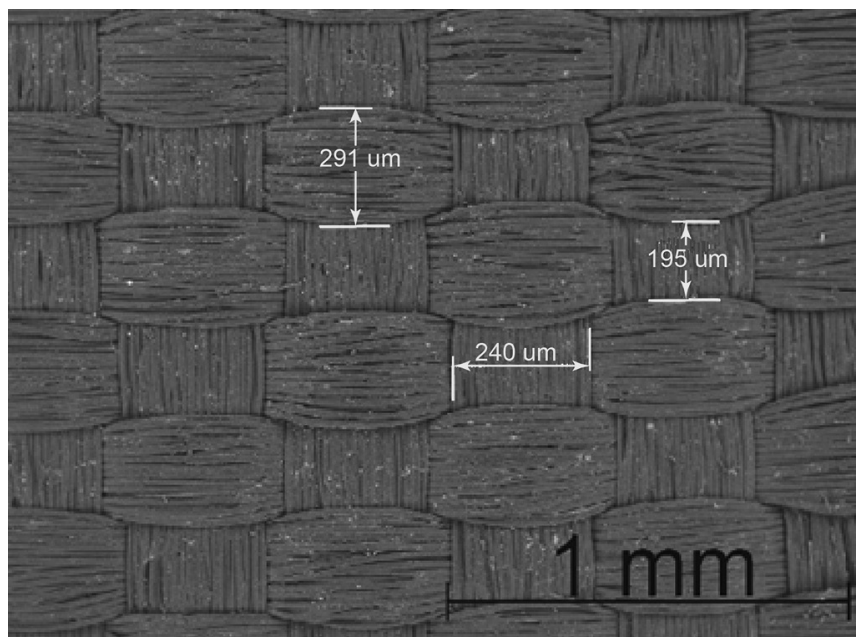

Figure 14. Dacron $3_{\mathrm{B}}$. Amplified SEM image $80 \times$.

Table 2. Dimensions of the measured fibers.

\begin{tabular}{|c|c|c|}
\hline Dacron $3_{\mathrm{T}}$ & Dacron $3_{\mathrm{M}}$ & Dacron $3_{\mathrm{B}}$ \\
\hline $300 \mu \mathrm{m}$ & $320 \mu \mathrm{m}$ & $297 \mu \mathrm{m}$ \\
\hline
\end{tabular}

The equipment controls the direction of the controlled air pressure against the material to be tested. To validate the design of the equipment, a prototype was built, using the laser cutting technology. Figure 16 shows the prototype, the air inlet and outlet

A3D scanner was used for curvature analysis (Figure 17). The main objective of the test was to obtain dimensional parameters and to compare material elasticity properties in five specimens. The wind speed was investigated using anemometry, with a constant speed of $13 \mathrm{~km} / \mathrm{h}$. To set up a zero reference point, the air outlet was scanned with no fabric or air circulation (Figure 17). 

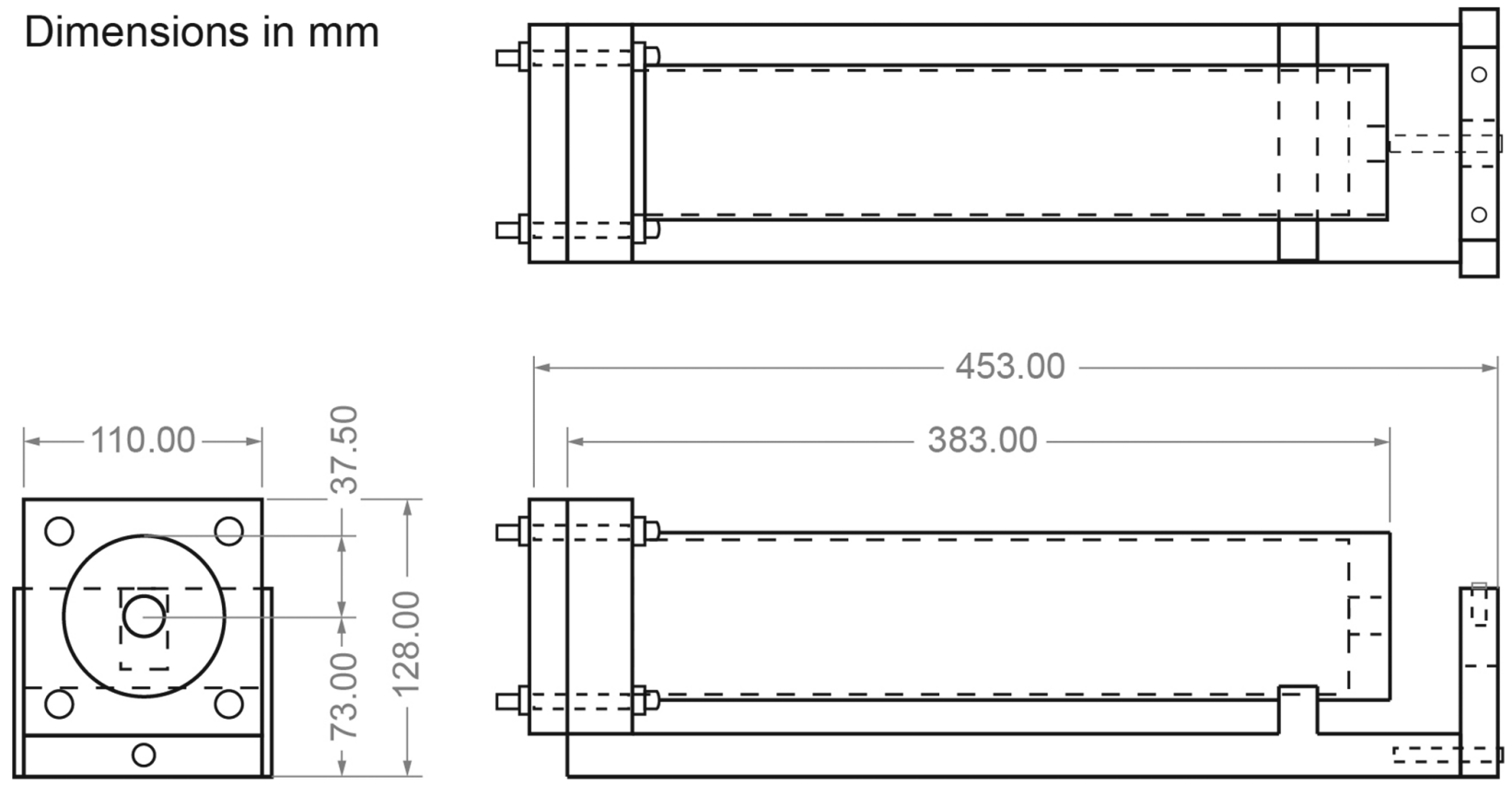

Figure 15. Schematic diagram of the wind tunnel.

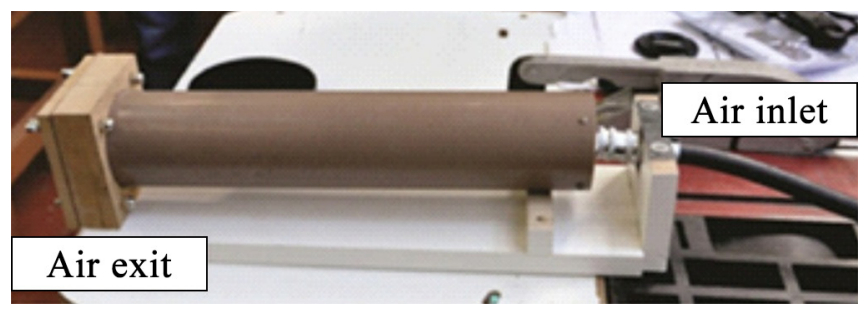

Figure 16. Wind tunnel prototype.

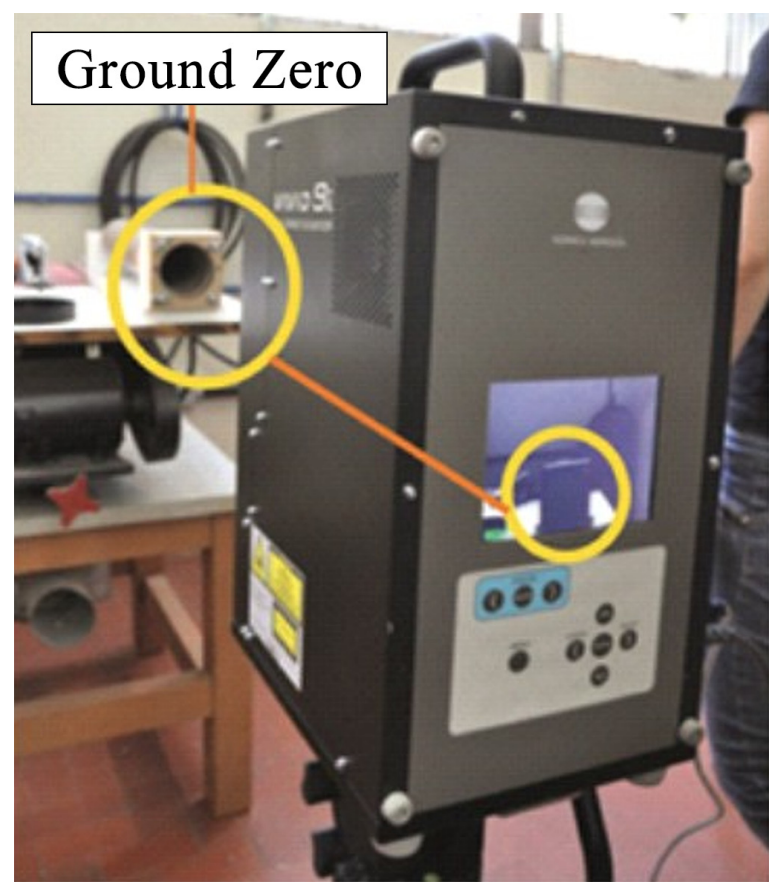

Figure 17. Prototype scanning to set up the zero point.

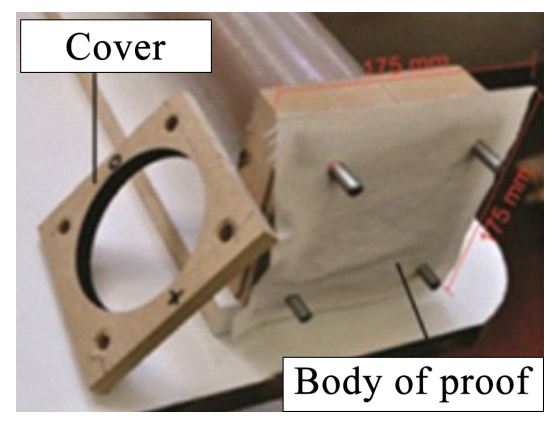

Figure 18. Placing the fabric in the wind tunnel.

Following, the specimen was introduced (Figure 18) and scanned with the air compressed turned on (Figure 19). In all five tests, there was no air leakage. The material was then disposed due to low performance.

Following the test with the five specimens, a graphic mesh was generated (Figure 20) to provide a comparative analysis of the materials.

After the analysis of the metric scale of the five scanned images, a curve was made using the points of the mesh. The results can be analyzed in Figure 21.

This analysis showed that Dacron $3_{\mathrm{M}}(7.31 \mathrm{~mm})$ created a bigger pocket when compared to Dacron $3_{\mathrm{T}}(7.24 \mathrm{~mm})$ and Dacron $3_{\mathrm{B}}(6.65 \mathrm{~mm})$. The Dacron $1(2.90 \mathrm{~mm})$ and Dacron 2 (2.88) samples served as reference and presented smaller pockets when stretched by the wind pressure.

Therefore, this test has confirmed what was verified in the SEM analysis. The wind pressure caused more abrasion in the middle of the sailcloth (Dacron $3_{\mathrm{M}}$ ) followed by the top of the sailcloth (Dacron $3_{\mathrm{T}}$ ). 


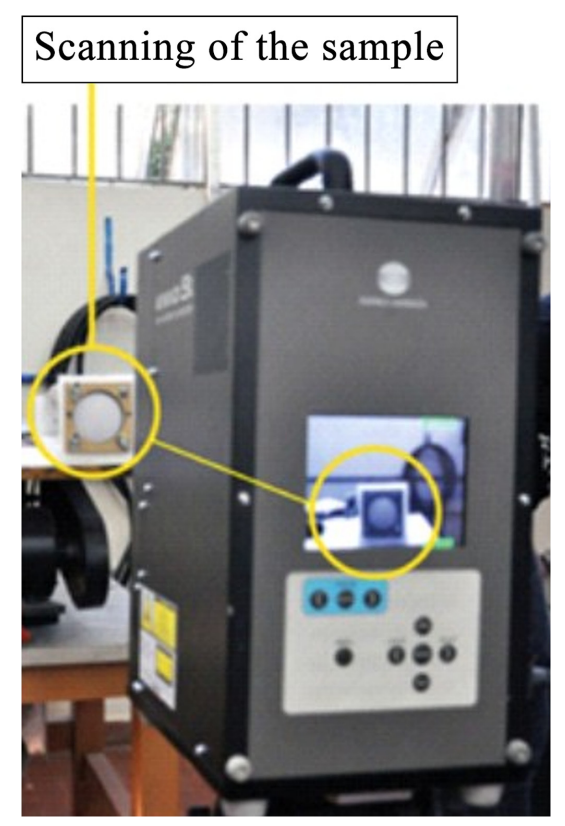

Figure 19. Fabric scanning.

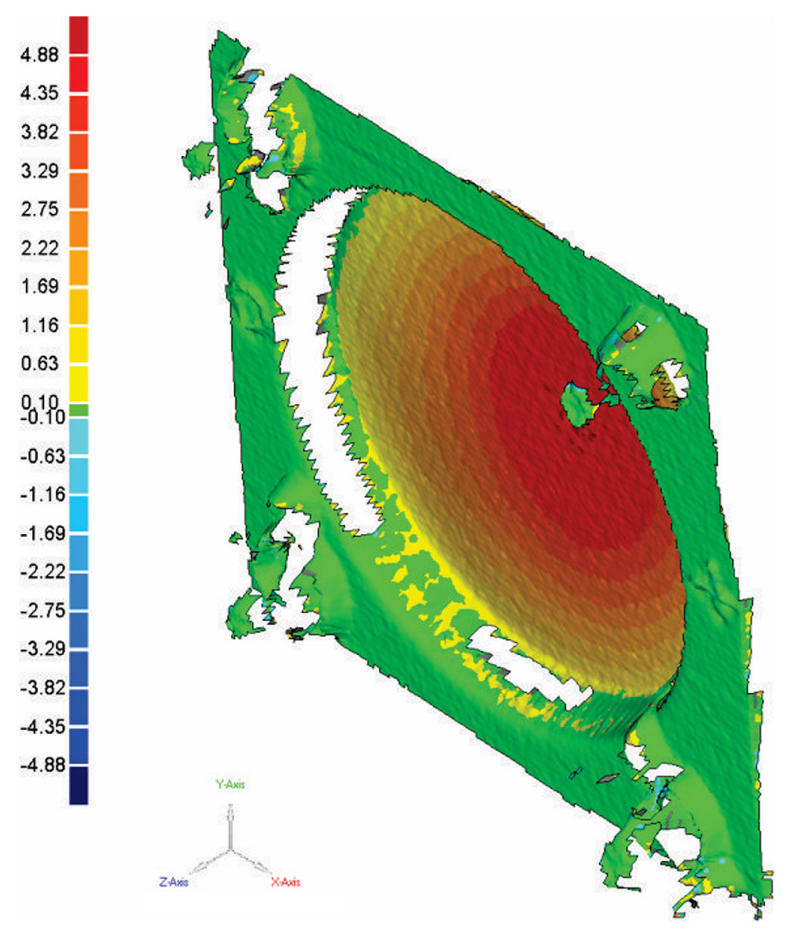

Figure 20. 3D scanning image.

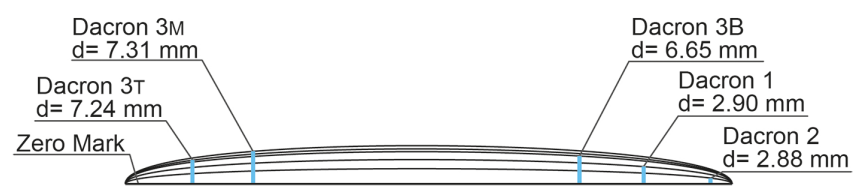

Figure 21. Curvatures of the fabric tested.

\section{Conclusion}

The types of cloth used in sails are technologically design to provide excellent performance and to use air pressure and their quality can make a difference in a sailing competition. The tests indicated that there is great stretch in the weave of the polyester fibers i.e. the threads are permanently apart. The sail cloth in the middle of the sail becomes so stretched that it causes a "cupping effect", which can negatively affect the performance of the boat. An important factor in a boat's performance is when those air pockets can be monitored. The lack of control provides false information in maneuverability, because this control is done visually by the crew, using a windsock that indicates wind direction and relative wind speed. This marine equipment is then discarded prematurely because it reduces the competitive performance of the boat.

The results obtained can help the designers to evaluate the extension of the life cycle of materials. Even if the discarded cloths are used in sailing for beginners' training, it is necessary to think about other possibilities, considering that, chemically, polyester has an extended life cycle and will be disposed permanently, even for non-professional use. The tests carried out were possible due to the development of a wind tunnel. It is innovative equipment and that can be applied, for example, to some water sports and parachuting. In conclusion, the present study aimed at demonstrating that the area of design can develop research tools for technical and scientific tests of products and materials.

\section{References}

ASSOCIAÇÃO BRASILEIRA DOS VELEJADORES DA CLASSE RGS. Regra da Classe Versão 2011c: anexo-1. 2011. Available from: <http://www.bra-rgs.com.br/Regra BRA-RGS\%202011c.pdf>. Access in: 15 Feb 2015.

AZEVEDO, G. As origens da navegação a vela. 2008. Available from: <http://www.guilhermeazevedo.com/ naveg/naveg23.PDF>. Access in: 10 June 2014.

BATISTA, H. G. Os sem-lancha da cidade classe A. O Globo [online], 14 oct. 2012. Available from: <http:// oglobo.globo.com/economia/os-sem-lancha-da-cidadeclasse-a-6398816>. Access in: 01 Mar 2015.

CAETANO, S. Princípio físico do velejar. Ilhabela: Escola de vela Oceânica, 2015. 5 p.

CÂNDIDO, L. H. A. Contribuição ao estudo da reutilização, redução e da reciclagem dos materiais com aplicação do ecodesign. Porto Alegre: Universidade Federal do Rio Grande do Sul, 2008. 130 p.

CHALLENGE SAILCLOTH. Understanding Cloth Selection. 2014. Available from: <http://www.challengesailcloth.com/ understanding-sailcloth/>. Access in: 15 Aug 2014

CHOWDHURY, H. Applied aerodynamics: aerodynamic performance evaluation of sports garments. Australia: InEch, 2012. 192 p. 
DOYLESAILS. Upwind Sails. 2015. Available from: < http:// www.doylesails.com/racing/upwind/>. Access in: 1 Mar 2015

DUARTE, O. História dos esportes. São Paulo: Senac São Paulo, 2003. 559 p.

KUASNE, A. Curso têxtil em malharia e confecção: fibras têxteis. Araranguá: CEFET/SC, 2008.90 p.

MÉRIDA, K. R.; FANGUEIRO, K. R. Arquitetura têxtil: liberdade de design, funcionalidade e sustentabilidade.
Revista de Design, Inovação e Gestão Estratégica, v. 3, n. 3, 20 p., 2012.

OLYMPIC SAILS. 2014. Available from: <http://www.olisails. com.br/>. Access in: 10 July 2014

PALMER, G. Physics for game programmers. New York: Copyright, 2005. chap. 9, 444 p.

SCHLEIFER, S. K. Sport design: four elements. New York: teNeues, 2004. chap. 1, 399 p. 